\title{
THE TREASON OF THE INTELLECTUALS AN ESSAY ABOUT THE HUNCARIAN LESSON
}

BALÁZS SZÉLINCER, PH.D.

ECONOMIC AND TRADE ATTACHÉ, EMBASSY OF HUNCARY IN ETHIOPIA

BSZELINCER@CMAIL.COM

\section{Abstract}

Keywords
As the subtitle indicates, this is not a scholarly article based on research but one almost identical to the oral presentation I gave during the workshop "30 Years of Freedom - Farewell to Communism in Hungary, Local and Global Lessons" in Addis Ababa on October 25, 2019, organized jointly by the Embassy of Hungary in Addis Ababa, the Ethiopian Civil Service University, the Hungarian National University of Public Service, and the University of Pécs, Hungary. I made every effort to strengthen my arguments with valuable references.

Ethiopian intellectuals, similar historical experiences, exchange of solutions 
"Plato is my friend, but truth is a better friend," said Aristotle, the great Greek philosopher already some 2200 years ago. Luckily, both of them, Plato and Aristotle, were Greek, moreover, from the same Ionic tribe. In 1927, another philosopher, the French Julien Benda published his famous book titled 'The Treason of the Intellectuals' (Benda, 1927; 2007). This is a book that is perhaps more talked about than read, most probably because of its catchy title. As Roger Kimball put it in the book's latest English translation, "Today, only the title of the book, not its argument, enjoys currency" (Benda, 2007: i). Indeed, for example, if one tries to Google the title in its Hungarian translation, dozens of hits will pop up from scholarly articles to tabloid ones using but rather misusing the title for the most various political interests from the far right to the far left. Those who did (and are doing) that, did exactly what the book's intention is in fact: betraying the entire society, humankind, and last but not least, themselves too.

I have spent almost exactly 30 years studying Ethiopia's history and culture, and I have always paid close attention to contemporary developments too. Therefore, I am well aware of what Ethiopian historian Bahru Zewde calls the missing generations of Ethiopian intellectuals. Almost an entire generation of the highest educated was killed by the Italians between 1936 and 1941. Later, they were persecuted (killed or forced into exile) by the Derg, which - even if to a lesser extent - was continued by the EPRDF regime (see, for example, Bahru, 1993; 2014). It is widely known too that most of the students of Ethiopia who were lucky to obtain a scholarship abroad never returned.

Yet, here I would like to put something on the table that is rarely or never mentioned regarding politics in Ethiopia - that is the responsibility and active role of intellectuals. We seldom witness this. Of course, it does not mean that there are no Ethiopian intellectuals. In fact, there are many. But they are silent and hiding in real or self-imposed exile, scared of real and imagined dangers. A silent and numb intellectual is not an intellectual. His or her education, knowledge, and morals are impotent and fruitless. Ethiopian philosopher Messay Kebede (who was chased away by the EPRDF government in 2005) argues that Ethiopia's failed modernization is due to the lack of "homegrown intellectuals":

"The great tragedy of Ethiopia is, therefore, that it did not produce domestic, homegrown intellectuals, who might have conceived of modernization as an upgrading of the traditional culture. Such intellectuals could have easily risen from the traditional culture if the system of education had established some form of continuity between traditional and Western educational systems" (Messay, 2008: 100).

But who is an intellectual, anyway? Every highly educated person? A medical doctor? An actor? A university professor of political science? By their education, none of them. Potentially, all of them. To be an intellectual is rather a lifestyle than just being spent several years in school. In my view, based on Aristotle's and Benda's philosophies, education may be a tool to be an intellectual but not one entirely attrib- 
uted to it. As one of the very few Ethiopian scholars who regularly address this topic, Maimire Mennasemay, a philosopher living and teaching in Canada, expressed:

"Though the subjects of political society are those who suffer from capabilities deprivations, the participation of intellectuals is vital; however, they cannot enjoy 'place-holder' functions for the underprivileged. The intellectuals' authority is not rooted in their knowledge-claims, but in the fact that their proposals speak to the emancipatory interests of the participants and enhance their capability sets" (Maimire, 2008: 27).

An intellectual is led by morals like the seeking of impartial truth and justice. An intellectual is empathetic to others from different ethnic groups, classes or political affiliations. He or she is actively seeking to transfer these values to others, and not only when their self-interest dictates that. Can a politician be an intellectual? Yes, but only when he or she is gifted with the ability (humbleness) to openly and immediately admit when the opposition is right. This is the exact reason why we do not find many intellectuals among politicians. And that is why real intellectuals have in fact the same responsibility as politicians, or even more than that. More importantly, an intellectual can never be radicalized or become an extremist, and this is where the otherwise excellent Messay Kebede is wrong, mixing up the educated and the intellectuals (Messay, 2006: 5-27).

Then a question arises: is there a demand for intellectuals in the society at all? There is so much debate about this in the age of mediocratic plutocrats. Anyway, the answer can be yes or no. I believe it is yes. If yes, then it is a big responsibility because if the real intellectuals keep silent, the demand will still seek for others and will find fake ones, self-appointed crooks and impostors. No need to explain how dangerous this is. And if anyone (especially one of those intellectuals) thinks that there is no demand, just remember what Leonardo di Caprio said in The Wolf of the Wall Street: "If there is no demand, then create the demand." And remember Lord Varys from the Game of Thrones: how many kings try to make him stand by their sides while the 'Spider' insists on serving "only" the realm itself. As Maimire Mennasemay put it, "If Ethiopian intellectuals are to play a constructive role in the creation of a democratic, prosperous, and just society, they need to 'think in front' and not 'on behalf' of the oppressed and exploited" (Maimire, 2008: 26).

One of my motivations to study Ethiopian history and culture was when I discovered the similarities between Ethiopia and Hun-

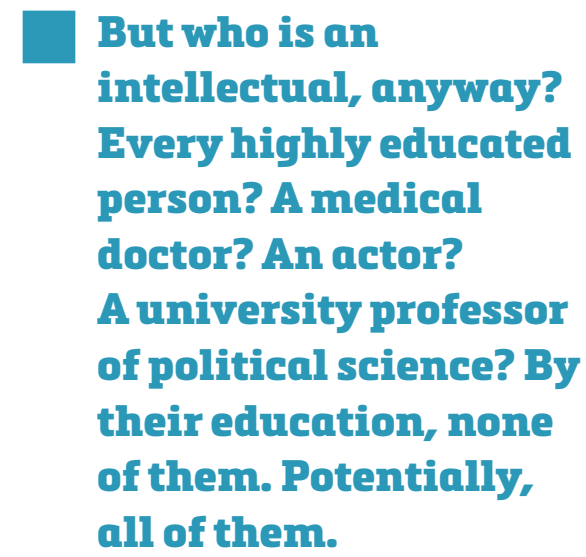


gary. Just like Ethiopian history, Hungarian history too is a constant fight against intruders, for independence, and for survival. Hungarians fought against the Muslims (Ottoman Turks) and finally lost the decisive Battle of Mohács in 1526. The similar decisive Battle of Shimbra Kure happened three years later in Ethiopia. The Habesha developed a sense of "mission identity," a Christian fortress to fight against Islam; in a similar way, the Hungarians considered themselves the "most Eastern bastion of Christianity' against the Turks. The Habesha referred (and the most religious still do) to their land as Tsion (Zion), meanwhile Sion (the Hungarian word for Zion, pronounced as "she-on") became a metaphor for Hungary in numerous religious songs and poems until the $20^{\text {th }}$ century. Paprika or berbere that had been brought to both countries by Muslim merchants became an essential ingredient in both national cuisines. We both lived under Communism, although the Ethiopians were lucky enough to suffer under it only for 17 years, while in Hungary it was more than four decades. I strongly believe that similar historical experiences cause similar reactions and mindsets. Therefore, I believe that we can learn from each other, too. What is going on in Ethiopia recently - extremely strong ethno-nationalist movements - is not uncommon for Hungarians, although by different historical experiences.

Careless observers - and in this world of social media they are the majority - may wonder where all the Ethiopians have disappeared. It seems today that in a country called Ethiopia, proud of her history and culture, everyone wants to be just Oromo, Somali, Amhara, Sidama, Tegaru, etc. It seems that all the Ethiopians are living abroad - at least that is what they answer when asked about their origin - or attend international sports competitions (and when they win, they may cross their arms when celebrating victory). Of course, one may find more Ethiopians in Addis Ababa, but remember that a capital city never reflects the true self of a country or a nation.

Here, this topic connects to intellectuals - and a somewhat similar historical trauma in Hungary (and nations are always forged by traumas, not happy times). In the 1930s, due to the racial laws enforced upon Hungary by the increasing German pressure, all Hungarians were forced to provide their own birth documents and those of their parents and grandparents. The criminal aim of the state was to know who had (and "up to what amount") Jewish blood in their veins. This essay is, however, not about the history of antisemitism in Hungary. The aforementioned laws forced the entire Hungarian population into an investigation of origin. The previous decades in Hungarian politics (and, therefore, in education as well) were spent under the motto of "one country, one nation," which brought the illusion that everybody who spoke Hungarian in the 1930s was a Hungarian. The search and the finding of birth certificates (many people had to travel for them extensively) caused shock and trauma. Hundreds of thousands of Hungarians had to realize that although their identity was absolutely Hungarian, there had been many non-Hungarians among their ancestors (sometimes the majority). I believe that if a similar large scale investigation of birth documents happened in Ethiopia now, the shocking surprise would be inevitable. In 1938 and 1939, perhaps half of the Hungarian population asked: "Who am I? - Am 
I a Hungarian at all? - What matters more? My mother tongue? My identity? My blood?"

The answer and the solution as a balm - medhanit, I would say - came from the intellectuals. It was a prominent historian, Gyula Szekfü, who got the idea to publish a volume titled 'What is Hungarian?' While Szekfü also contributed to the volume, he asked other twelve intellectuals to write their piece on their respective fields (Szekfü, 1939). Others completed the task later, publishing influential articles in different journals. As you may expect, the majority were not politicians but historians, religious leaders, ethnographers, art historians, musicologists, etc. They together, as an "intellectual army," provided the healing of a nation. They kept the majority of Hungarians away from narrow nationalism and provided guidance by delivering a message that can be summed up as "If you feel Hungarian, you are a Hungarian, whatever your name sounds or however your blood is mixed."

I believe that Ethiopians are in need of something similar to that now. Imagine artists, religious leaders, musicians, etc. writing their short pieces, from Humera to Jigjiga and from Semera to Jinka, under the same title: "What is to be Ethiopian?" I truly believe that the answers would surprise everyone

\section{Notes}

1 I used the English translation of Richard Aldington (Benda, 2007).

2 I am reflecting here that identity always has different layers, and these are dynamic: in a foreign environment the Ethiopian layer may get stronger, and in international sports competitions all Ethiopians are supposed to celebrate the Ethiopian victory. Yet, the reader may remember silver medalist Feyisa Lilesa at the Rio Olympic Games crossing his arms - which became a widespread symbol of Oromo protests against the Ethiopian government from then on.

3 I mention here that while it is relatively widely known among the population of Ethiopia that Emperor Haile Selassie I had a very mixed origin of Amhara, Gurage Oromo, and Tegaru (and perhaps more if we go back in time), people rarely talk about their own mixed origin and refer to Haile Selassie as the 'Amhara ruler.'

\section{References}

- Bahru Z. (1993). The Ethiopian intelligentsia and the Italo-Ethiopian war, 1935-1941. The International Journal of African Historical Studies 26 (2), 271-295.

- Bahru Z. (2014). The Quest for Socialist Utopia: The Ethiopian Student Movement, c. 19601974. James Currey, Suffolk.

- Maimire M. (2008). A millennium democratic goal for Ethiopia: some conceptual issues. Africa Today 55 (1), 3-32.

- Márkus, B. (2018). What is the Hungarian? MMA Publishing, Budapest.

- Messay K. (2008). Radicalism and Cultural Dislocation in Ethiopia, 1960-1974. University of Rochester Press, Rochester.

- Messay K. (2006). The Roots and Fallouts of Haile Selassie's Educational Policy. UNESCO Forum Occasional Paper Series, Paper No. 10. Philosophy Faculty Publications, University of Dayton.

- Szekfü, Gy. (Ed). (1939). Mi a magyar? [What Is Hungarian?] Magyar Szemle Társaság, Budapest. 